\title{
In vitro antimicrobial activity on clinical microbial strains and antioxidant properties of Artemisia parviflora
}

\author{
Abdul R Ahameethunisa and Waheeta Hopper
}

\begin{abstract}
Background: Artemisia parviflora leaf extracts were evaluated for potential antimicrobial and antioxidant properties. Antimicrobial susceptibility assay was performed against ten standard reference bacterial strains. Antioxidant activity was analyzed using the ferric thiocyanate and 2, 2-Diphenyl-1-Picrylhydrazyl (DPPH) assays. Radical scavenging activity and total phenolic content were compared. Phytochemical analyses were performed to identify the major bioactive constitution of the plant extract.
\end{abstract}

Results: Hexane, methanol and ethyl acetate extracts of A. parviflora leaves exhibited good activity against the microorganisms tested. The n-hexane extract of A. parviflora showed high inhibition of the growth of Pseudomonas aeruginosa, Escherichia coli and Shigella flexneri. Methanol extract showed strong radical scavenging and antioxidant activity, other extracts showed moderate antioxidant activity. The major derivatives present in the extracts are of terpenes, steroids, phenols, flavonoids, tannins and volatile oil.

Conclusions: The results obtained with $n$-hexane extract were particularly significant as it strongly inhibited the growth of $P$. aeruginosa, E. coli and S. flexneri. The major constituent of the n-hexane extract was identified as terpenes. Strong antioxidant activity could be observed with all the individual extracts. The antimicrobial and antioxidant property of the extracts were attributed to the secondary metabolites, terpenes and phenolic compounds present in A. parviflora and could be of considerable interest in the development of new drugs.

Keywords: Artemisia, Terpenoids, Antimicrobial, Antioxidant, Radical scavenging activity

\section{Background}

Artemisia belonging to the family Asteraceae is known for their essential oils. More than 400 species of Artemisia have been explored from different parts of the world. The strong aroma and bitter taste of Artemisia are from the terpenoids and sesquiterpene lactones, constituents of the essential oil [1]. Essential oils of Artemisia spp. have been widely used for a variety of medicinal purposes such as antimalarial, antibacterial, antiviral, nematicidal and fungicidal for many years [2-7]. A. parviflora is an aromatic shrub, about 30$90 \mathrm{~cm}$ in height, found throughout the greater part of India at altitudes of 900-3000 m [8]. A. parviflora yields a light yellow essential oil which contains isobornyl

\footnotetext{
* Correspondence: srmbioinforesearch@gmail.com Department of Bioinformatics, School of Bioengineering, Faculty of Engineering \& Technology, SRM University, Kattankulathur, Tamil Nadu 603203, India
}

acetate (7.2\%), ar-curcumene (4.7\%), limonene (1.6\%), propanol $(1.2 \%)$ as the identified components and an unidentified portion $(77.9 \%)$. Later from the unidentified portion of A. parviflora essential oil, B- caryophyllene, germacrene $\mathrm{D}$, camphor and artemisia ketone were identified as the major constituents [9].

Antibiotic resistance by microorganisms causing infectious diseases has become a global concern in recent years. The worldwide emergence of multi-drug resistant Escherichia coli, Klebsiella pneumoniae, Pseudomonas aeruginosa and many other ß-lactamase producers has become a major therapeutic problem. Plants are valuable sources of natural products. The use of compounds from Artemisia spp. for pharmaceutical purposes has gradually increased [10-15]. Antimicrobial activity by Artemisia spp. against multi-drug resistant strains of Bacillus subtilis, Staphylococcus aureus, E. coli, K. pneumoniae and $P$. aeruginosa, opportunistic pathogens widely 
distributed in hospitals as well as increasingly being isolated from community acquired infections, have been reported [16-18].

Knowledge of the chemical constituents of plants is desirable, not only for the discovery of therapeutic agents, but also because such information may be of value in disclosing new sources. Conventionally available synthetic antibacterial and antioxidant drugs are often associated with undesirable side effects and antibacterial drug resistance problem. The use of phytochemicals with known antimicrobial properties can be of great significance in therapeutic treatment of resistant strains and clinical pathogens. Artemisia species were reported for high content of phenolic and flavonoids which possess strong antioxidant properties and radical scavenging activities [19-21]. In this study, the antimicrobial activity of various extracts of $A$. parviflora was studied against clinical pathogens. The phytochemical composition and the assessment of the antioxidant potential of the crude extracts were also tested.

\section{Methods}

\section{Plant material and extraction}

The fresh plant of Artemisia parviflora was collected from Tropical Botanical Gardens, Trivandrum, Kerala. The plant specimen was authenticated and voucher specimen (SRMU/BI/4) was deposited in the Herbarium at Proteomics lab, SRM University. The leaves were dried under shade. After drying for a week, the leaves were powdered and sieved using gauze cloth. The samples were stored in air tight containers and maintained at $4^{\circ} \mathrm{C}$.

The plant sample of $A$. parviflora was extracted using soxhlet extraction apparatus. Ten grams each of the powered sample was individually packed in muslin cloth and used for extraction at a temperature below the boiling temperature of each solvent, for 48 hours. Each $100 \mathrm{~mL}$ of solvents such as methanol, ethanol, chloroform, n-hexane, petroleum ether, ethyl acetate and acetone were used for the extractions. The extract was filtered through Whatman No.1 filter paper and concentrated using a rotary evaporator. The residue was dissolved in sterile DMSO (9:1) in $50 \mathrm{mg} \mathrm{mL}^{-1}$ concentration. The extract was filtered using $0.45 \mu$ solvent-resistance filter (Millipore GV $0.45 \mu$ ) and stored at $4^{\circ} \mathrm{C}$ until use.

\section{Antimicrobial screening and susceptibility assay}

The antimicrobial activity of the crude extracts of leaf was determined by the disc diffusion method [22] against the clinical microbial strains listed in Table 1. The test cultures maintained in nutrient agar slant at $4^{\circ} \mathrm{C}$ were sub-cultured in nutrient broth to obtain the working cultures approximately containing $10^{6}$ CFU mL $\mathrm{mL}^{-1}$.

The extracts were incorporated in a $5 \mathrm{~mm}$ sterile disc at a concentration of $500 \mu \mathrm{g} /$ disc. After complete saturation, the discs were dried overnight in a sterile chamber and used for screening for antimicrobial activity. Mueller Hinton (MH) agar plates were swabbed with each bacterial strain and the test disks were placed along with the control disks. Ampicillin or streptomycin disks $(10 \mu \mathrm{g} /$ disc $)$ were taken as positive control and 10\% dimethyl sulfoxide (DMSO) was taken as the negative solvent control. Plates were incubated overnight at $37^{\circ} \mathrm{C}$. Clear, distinct zone of inhibition was visualized surrounding the discs. The antimicrobial activity of the test agents was determined by measuring the zone of inhibition expressed in $\mathrm{mm}$.

The potential effectiveness of $A$. parviflora extracts was tested on all isolates by agar dilution susceptibility test. To determine the Minimum Inhibitory Concentration (MIC),

Table 1 Antimicrobial activity screening of Artemisia parviflora leaf extracts by disk diffusion method

\begin{tabular}{|c|c|c|c|c|c|c|c|c|c|}
\hline \multirow[t]{2}{*}{ Bacterial strains } & \multicolumn{9}{|c|}{ Zone of inhibition (diameter in $\mathrm{mm}$ ) } \\
\hline & $\begin{array}{l}\text { Positive } \\
\text { control }\end{array}$ & $\begin{array}{l}\text { Solvent } \\
\text { control }\end{array}$ & $\begin{array}{c}\text { Ethyl } \\
\text { acetate }\end{array}$ & Ethanol & Methanol & Chloroform & $\mathrm{N}-\mathrm{Hexane}$ & $\begin{array}{c}\text { Petroleum } \\
\text { ether }\end{array}$ & Acetone \\
\hline Bacillus subtilis (MTCC 441) & 20 & - & $14 \pm 0.0$ & $12 \pm 0.0$ & $16 \pm 0.0$ & $14 \pm 0.5$ & $14 \pm 0.0$ & $10 \pm 0.5$ & - \\
\hline Staphylococcus aureus (MTCC 29212) & 21 & - & $14 \pm 0.1$ & $12 \pm 0.5$ & $16 \pm 0.5$ & $15 \pm 0.0$ & $17 \pm 0.0$ & - & - \\
\hline Escherichia coli (ATCC 25922) & 20 & - & $12 \pm 0.5$ & $13 \pm 0.0$ & $17 \pm 0.5$ & $14 \pm 0.0$ & $18 \pm 1.0$ & $9 \pm 0.0$ & $11 \pm 0.0$ \\
\hline Yersinia enterocolitica (MTCC 840) & 17 & - & $15 \pm 0.5$ & $11 \pm 0.5$ & $15 \pm 0.0$ & $11 \pm 0.5$ & $15 \pm 0.0$ & $12 \pm 0.0$ & $13 \pm 0.0$ \\
\hline Proteus vulgaris (MTCC 1771) & 16 & - & $12 \pm 0.5$ & $9 \pm 0.0$ & $13 \pm 0.0$ & $11 \pm 0.5$ & $13 \pm 0.0$ & $9 \pm 1.0$ & $11 \pm 0.0$ \\
\hline Pseudomonas aeruginosa (ATCC 27853) & 21 & - & $14 \pm 0.0$ & - & $16 \pm 0.0$ & - & $18 \pm 0.5$ & - & - \\
\hline Klebsiella pneumonia (ATCC 15380) & 18 & - & $13 \pm 0.0$ & - & $14 \pm 0.0$ & $10 \pm 0.5$ & $16 \pm 0.5$ & - & - \\
\hline Shigella flexneri (MTCC 1457) & 20 & - & $14 \pm 0.5$ & - & $15 \pm 0.5$ & $13 \pm 0.5$ & $18 \pm 0.0$ & $12 \pm 1.0$ & $12 \pm 0.0$ \\
\hline Enterococcus faecalis (ATCC 29212) & 21 & - & $14 \pm 0.5$ & $11 \pm 0.0$ & $13 \pm 0.5$ & $12 \pm 1.0$ & $14 \pm 0.5$ & $11 \pm 0.0$ & $12 \pm 0.5$ \\
\hline Enterobacter aerogenes (MTCC 111) & 18 & - & $13 \pm 0.5$ & $12 \pm 0.0$ & $13 \pm 0.5$ & $11 \pm 0.0$ & $14 \pm 1.0$ & $11 \pm 0.0$ & $11 \pm 1.0$ \\
\hline
\end{tabular}

\pm- mean standard deviation of triplicates, concentration of the extract $5 \mathrm{mg} /$ dick. (-) No clear zone of inhibition was observed around the disk. Positive controls, ampicilin or streptomycin $\left(10 \mu \mathrm{g} \mathrm{m}^{-1}\right)$. Solvent control - 10\% DMSO. 
test was performed based on modified method of NCCLS and CLSI [23,24]. Series of twofold dilutions were made to obtain a final concentration of the extracts in the agar medium ranging of $512 \mu \mathrm{g} \mathrm{mL} \mathrm{L}^{-1}$ to $16 \mu \mathrm{g} \mathrm{mL}$. Pour plates were prepared and $2 \mu \mathrm{L}$ of overnight grown cul-

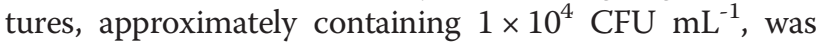
spotted on solidified plates. The extract concentration showing $\geq 99 \%$ inhibition of visible colony growth is taken as the MIC for that organism.

\section{Phytochemical screening of constituents of $A$. parviflora}

Standard phytochemical screening was performed to characterize the phytochemical constituents in the leaf extracts, [25,26]. Dragendorff's and Meyer's tests were used to test for alkaloids. The formation of reddish brown precipitate with Dragendorff's reagent and cream with Mayer's reagent was regarded as positive for the presence of alkaloids. Steroids were tested by Liebermann-Burchard test. Colour development form violet to blue or bluishgreen indicate the presence of a steroid. Terpenoids were tested by Salkowski test, a reddish brown coloration of the interface indicates the presence of terpenoids. Copper acetate test was performed to identify the presence of diterpenes; formation of emerald green colour indicates the presence of diterpenes. Presence of triterpenoids was tested by Hirschhorn test; the change of yellow colour to red indicates the presence of triterpenoids. The formation of yellow colored layer in Salkowski test also indicated the presence of triterpenoids. Flavonoids are tested by $\mathrm{FeCl}_{3}$, lead ethanoate, Pew's and Shinoda's tests [27]. A greenblue or violet coloration by $\mathrm{FeCl}_{3}$, appearance of buffcoloured precipitate by lead ethanoate and Pink-tomato red coloration by Shinoda's test indicated the presence of flavonoids in the extract.

Presence of tannins was checked by neutral ferric chloride and lead acetate tests, brownish green colour indicates the presence of tannins. The extract was treated with few drops of gelatin solution, the formation of white precipitate reveals the presence of phenols. Glycosides were tested by Fehling test. A deep red color which faded to brownish yellow indicates the presence of glycosides. Presence of saponins was tested by frothing test, frothing which persisted on warming was taken as an evidence for the presence of saponins. Borntrager's test was performed to identify the presence of anthraquinones, appearance of a pink or violet colour in the lower phase was taken as the presence of free anthraquinones. The test for amino acids by ninhydrin, carbohydrates by Barfoed's test, hydrolysable tannins, phlobatannins, resins, quinones and volatile oils were also carried out with little modification $[26,28,29]$.

\section{Determination of total phenolic contents}

The total phenolic content in A. parviflora extracts was determined using a modified Folin-Ciocalteu method
[30,31]. $200 \mu \mathrm{L}$ of sample was mixed with $2.6 \mathrm{~mL}$ of distilled water, $200 \mu \mathrm{L}$ of Folin-Ciocalteu's phenol reagent was added to each tube. The content was vortexed and incubated for $5 \mathrm{~min}$. Then $2 \mathrm{~mL}$ of $7 \% \mathrm{Na}_{2} \mathrm{CO}_{3}$ was added to each tube. The content in the tube was vortexed and incubated for $2 \mathrm{~h}$ with intermediate shaking. The absorbance of sample was read in spectrophotometer (Ultrospec 2100 pro, Amersham biosciences) at $725 \mathrm{~nm}$. The total phenolic content is expressed as milligrams of Gallic acid per gram of dry extract.

\section{Antioxidant activity evaluation by ferric thiocyanate method}

The antioxidant activity of $A$. parviflora leaf extracts were determined using FTC method [32]. Samples were dissolved in ethanol $\left(1 \mathrm{mg} \mathrm{mL}^{-1}\right)$. To $1 \mathrm{~mL}$ of sample, $1 \mathrm{~mL}$ of $2.5 \%$ linoleic acid in ethanol and $2 \mathrm{~mL}$ of $0.02 \mathrm{M}$ phosphate buffer ( $\mathrm{pH} 7.0)$ were added and the volume is made up to $5 \mathrm{~mL}$ using distilled water. The mixture was incubated at $40^{\circ} \mathrm{C}$ for $96 \mathrm{~h}$. At every $12 \mathrm{~h}$ interval, $0.1 \mathrm{~mL}$ from each vial was diluted with $9.7 \mathrm{~mL}$ of $75 \%$ ethanol, $0.1 \mathrm{~mL}$ of $30 \%$ aqueous ammonium thiocyanate and $0.1 \mathrm{~mL} 0.02 \mathrm{M} \mathrm{FeCl}_{2}$ in $3.5 \%$ hydrochloric acid. After three minutes of incubation the absorbance of the resulting red colour was measured at $532 \mathrm{~nm}$. Tert-butyl-1hydroxyl toluene (BHT) was used as a positive control while the ethanol without sample was used as a negative control. The antioxidant activity was carried out in triplicates. The Percentage of lipid peroxidation inhibition was calculated by the following formula,

\section{Percentage of Lipid Peroxidation Inhibition (\%LPI)$$
=\frac{A_{532} \text { Control }-A_{532} \text { Sample }}{A_{532} \text { Sample }} \times 100
$$

Where $\mathrm{A}_{532}$ control is the absorbance of the control and $A_{532}$ Sample is the absorbance of sample.

\section{2, 2-Diphenyl-1-Picrylhydrazyl (DPPH) scavenging activity}

Hydrogen atom or electron donation ability was measured as the radical-scavenging activity. DPPH assay $[33,34]$ was used to determine the radical scavenging activity of methanol and hexane leaf extract of A. parviflora. DPPH, a purple color solution, reacts with an antioxidant compound present in the test extracts, it is reduced to yield a light-yellow color diphenylpicrylhydrazyl which can be spectrophotometrically measured. To $4 \mathrm{~mL}$ of leaf extracts, $1 \mathrm{~mL}$ of $0.2 \mathrm{mM} \mathrm{DPPH}$ methanol solution was added. After incubating for $30 \mathrm{~min}$ in dark, the absorbance of the resulting solutions was measured at $517 \mathrm{~nm}$ using a spectrophotometer. Distilled water was used instead of sample as negative control. BHT and $\alpha$-Tocopherol were used as positive controls. All the tests were carried out in triplicates. The 
Radical scavenging activity was calculated according to the equation:

\section{Percentage of Radicals Scavenging Activity (\%RSA) $=\frac{A_{517} \text { Control }-A_{517} \text { Sample }}{A_{517} \text { Sample }} \times 100$}

Where $\mathrm{A}_{517}$ control is the absorbance of the control and $A_{517}$ Sample is the absorbance of samples.

\section{Statistical analysis}

All analyses were done in triplicates in order to determine their reproducibility. The results were expressed as mean \pm SD. Analysis of variance (ANOVA) was performed using Graph pad prism and Excel 2007. The probability value $(\mathrm{p} \leq 0.05)$ was considered as significance.

\section{Results}

The A. parviflora leaf extracts were tested for antimicrobial activity against ten clinically important microorganisms using agar dilution method. All the extracts of $A$. parviflora exhibited considerably broader inhibitory activity for the most of the test organisms (Table 1). High zone of inhibition was observed for n-hexane extract against E. coli, S. flexneri and P. aeruginosa $(18 \mathrm{~mm})$. The n-hexane, ethyl acetate and methanol extracts showed good activity compared to the other extracts. The minimum inhibitory concentration for $\mathrm{n}$-hexane, ethyl acetate and methanol extracts of $A$. parviflora ranged from 32-64 $\mu \mathrm{g} \mathrm{mL}^{-1}$ for all the microbes tested (Table 2). Growth of $P$. aeruginosa was inhibited by $\mathrm{n}$ hexane $(18 \mathrm{~mm})$, methanol $(16 \mathrm{~mm})$ and ethyl acetate (14 mm) extracts with the MIC value of $32 \mu \mathrm{g} \mathrm{mL}^{-1}$.

Higher inhibition zone was observed with n-hexane $(16 \mathrm{~mm})$ for $K$. pneumoniae while other extracts showed comparatively low inhibition zones. MIC of n-hexane extract was observed to be $32 \mu \mathrm{g} \mathrm{mL}^{-1}$ for K. pneumoniae. Ethyl acetate, methanol and chloroform extracts showed MIC in the range from $64-128 \mu \mathrm{g} \mathrm{mL}^{-1}$ for $K$. pneumoniae. Chloroform extract was equally effective against all the test microbes other than $P$. aeruginosa, with MIC ranging from $32-128 \mu \mathrm{g} \mathrm{mL}{ }^{-1}$. Ethanol, petroleum ether and acetone extracts showed moderate antimicrobial activity against many test microbes but showed no antimicrobial activity against $P$. aeruginosa and $K$. pneumoniae. Ethanol extract was inactive for $S$. flexneri whereas moderate activity was observed for other test microbes with the MIC ranging from 64 to $256 \mu \mathrm{g} \mathrm{mL} \mathrm{m}^{-1}$. Petroleum ether and acetone extracts showed no inhibition against $S$. aureus. Acetone extract showed no inhibition for $B$. subtilis. MIC value for petroleum ether and acetone extract were higher (MIC > $64 \mu \mathrm{g} \mathrm{mL}^{-1}$ ) for the rest of the bacteria tested.

Phytochemical screening of A. parviflora extracts showed positive result for the alkaloids, steroids, terpenoids, di- and triterpenoids, flavonoids, tannins, phenols and volatile oils [Table 3]. The n-hexane and methanol extracts from A. parviflora showed abundant terpenoids, diterpenoids, triterpenoids and volatile oil. Ethyl acetate extract showed abundant terpenoids. Tannins, hydrolysable tannins and phlobatannins were found in methanol, ethanol and n-hexane extracts. None of the extracts showed positive for glycosides, saponin, amino acids, carbohydrates, resins, quinones, and anthraquinones. Previous study had demonstrated that essential oil of $A$. parviflora is rich in terpenoids and steroids [9].

The total phenolic content of various extracts of $A$. parviflora is shown in Table 4. The total phenolic content of A. parviflora ranges from 37.18 to $15.30 \mathrm{mg} \mathrm{mL}^{-1}$ gallic acid equivalent (GAE) in $100 \mathrm{~g}$ of the dry sample. Methanol extract of A. parviflora contained high amount of phenolics $\left(37.18 \pm 3.78 \mathrm{mg} \mathrm{mL}^{-1}\right.$ GAE)

Table 2 Minimum Inhibitory Concentration (MIC) of various solvent extracts of Artemisia parviflora against test microorganisms

\begin{tabular}{|c|c|c|c|c|c|c|c|}
\hline \multirow[t]{2}{*}{ Bacterial strains } & \multicolumn{7}{|c|}{$\mathrm{MIC} \mu \mathrm{g} \mathrm{mL}^{-1}$} \\
\hline & Ethyl acetate & Ethanol & Methanol & Chloroform & N- Hexane & Petroleum ether & $\overline{\text { Acetone }}$ \\
\hline Bacillus subtilis & 32 & 64 & 32 & 32 & 32 & 64 & 128 \\
\hline Staphylococcus aureus & 32 & 64 & 32 & 32 & 32 & * & * \\
\hline Escherichia coli & 32 & 64 & 32 & 32 & 32 & 128 & 128 \\
\hline Yersinia enterocolitica & 32 & 256 & 32 & 64 & 32 & 128 & 64 \\
\hline Proteus vulgaris & 64 & 256 & 64 & 64 & 64 & 128 & 256 \\
\hline Pseudomonas aeruginosa & 32 & * & 32 & * & 32 & * & * \\
\hline Klebsiella pneumoniae & 64 & * & 64 & 128 & 34 & * & * \\
\hline Shigella flexneri & 32 & * & 32 & 32 & 32 & 128 & 256 \\
\hline Enterococcus faecalis & 32 & 256 & 64 & 64 & 32 & 128 & 128 \\
\hline Enterobacter aerogenes & 32 & 64 & 64 & 128 & 32 & 128 & 256 \\
\hline
\end{tabular}

* No inhibition was observed up to $512 \mu \mathrm{g} \mathrm{mL}{ }^{-1}$. 
Table 3 Phytochemical constituents of various solvent extracts of Artemisia parviflora

\begin{tabular}{|c|c|c|c|c|c|c|c|}
\hline \multirow[t]{2}{*}{ Phytochemicals Screened } & \multicolumn{7}{|c|}{ Extracts } \\
\hline & Ethyl Acetate & Ethanol & Methanol & Chloroform & N- Hexane & Petroleum Ether & Acetone \\
\hline Alkaloids & + & ++ & ++ & ++ & + & + & + \\
\hline Steroids & ++ & + & ++ & ++ & + & + & + \\
\hline Terpenoids & ++ & + & ++ & + & ++ & + & + \\
\hline Diterpenoids & ++ & + & ++ & + & ++ & - & - \\
\hline Triterpenoids & ++ & + & ++ & + & ++ & - & - \\
\hline Flavonoids & + & + & ++ & + & + & + & - \\
\hline Tannins & - & + & ++ & - & + & - & - \\
\hline Phenols & + & + & ++ & + & + & + & + \\
\hline Glycosides & - & - & - & - & - & - & - \\
\hline Saponin & - & - & - & - & - & - & - \\
\hline Amino acid & - & - & - & - & - & - & - \\
\hline Carbohydrates & - & - & - & - & - & - & - \\
\hline Hydrolysable Tannins & - & - & + & - & + & - & - \\
\hline Phlobatannins & - & - & + & - & - & - & - \\
\hline Resins & - & - & - & - & - & - & - \\
\hline Quinones & - & - & - & - & - & - & - \\
\hline Volatile oils & + & + & ++ & ++ & ++ & + & + \\
\hline Anthraquinones & - & - & - & - & - & - & - \\
\hline
\end{tabular}

$(++)$ detected abundant, (+) detected, (-) not detected.

followed by ethyl acetate extract $\left(23.633 \pm 2.2 \mathrm{mg} \mathrm{mL}^{-1}\right.$ GAE). Ethanol and n-Hexane extracts had relatively moderate total phenolic content of $19.307 \pm 2.33$ and $19.7422 \pm 3.4 \mathrm{mg} \mathrm{mL}^{-1} \mathrm{GAE}$ representatively. The phenolic content of chloroform, petroleum ether and acetone extracts ranged from 17.5-15.3 mg GAE. Equation of the regression line formula correlation coefficient were $\mathrm{Y}=0.9004 \mathrm{X}+0.1562$ and $\mathrm{r}^{2}=0.9940$ with $\mathrm{p}<0.001$.

Table 4 Antioxidant, free radical scavenging activity and total phenolic content of various solvent extracts of Artemisia parviflora

\begin{tabular}{lccc}
\hline \multicolumn{1}{c}{ Extracts } & \multicolumn{2}{c}{ Antioxidant activity } & TPC mg mL \\
\cline { 2 - 3 } & DPPH Assay (\%) & FTC (\%) & \\
\hline BHT & $80.00 \pm 0.5$ & $82.23 \pm 0.5$ & $\mathrm{NA}$ \\
a-Tocopherol & $65.70 \pm 1.5$ & $73.17 \pm 0.2$ & $\mathrm{NA}$ \\
Ethanol & $60.83 \pm 1.6$ & $60.04 \pm 0.4$ & $19.74 \pm 3.40$ \\
Methanol & $85.11 \pm 1.0$ & $78.42 \pm 0.9$ & $37.18 \pm 3.78$ \\
Chloroform & $55.27 \pm 1.1$ & $50.74 \pm 0.2$ & $17.44 \pm 4.32$ \\
n-Hexane & $57.14 \pm 1.3$ & $55.61 \pm 0.3$ & $19.30 \pm 2.33$ \\
Acetone & $45.99 \pm 1.0$ & $40.18 \pm 0.3$ & $15.30 \pm 2.33$ \\
Petroleum ether & $43.29 \pm 1.0$ & $49.20 \pm 0.2$ & $15.62 \pm 1.80$ \\
Ethyl acetate & $68.01 \pm 0.5$ & $61.51 \pm 0.2$ & $23.63 \pm 2.20$ \\
\hline
\end{tabular}

\pm - mean standard deviation of triplicates, NA - not applicable. DPPH - 2, 2Diphenyl-1-Picrylhydrazyl, FTC - ferric thiocyanate, TPC- Total Phenolic content, BHT- Tert-butyl-1- hydroxyl toluene.
The antioxidant activity of $A$. parviflora extracts was determined by the peroxidation of linoleic acid emulsion using ferric thiocyanate method. Low absorbance values in the FTC method indicate a high level of antioxidant activity during emulsion incubation. Peroxide formation during emulsion was compared with BHT and $\alpha$-tocopherol as standard samples. BHT and $\alpha$-tocopherol (50 $\mu \mathrm{g}$ $\mathrm{mL}^{-1}$ ) inhibited $82.6 \%$ and $73 \%$ peroxidation of linoleic acid emulsion respectively. Methanol extract showed a significantly strong antioxidant activity (78.42 \pm 0.9 ). Ethyl acetate, ethanol, hexane and chloroform extracts of $A$. parviflora were less effective than the methanol extract and the activity ranged from $61.51 \pm 0.2$ to $50.74 \pm$ $0.2 \%$. Though these extracts contained less abundant of flavonoids and tannins, they showed moderate antioxidant activity. The petroleum ether and acetone extracts showed less antioxidant activity (49.20 \pm 0.2 and $40.18 \pm 0.3 \%)$.

The free radical scavenging activity of $A$. parviflora extracts was assessed by the DPPH assay. DPPH is a stable nitrogen centered free radical which can be effectively scavenged by antioxidants. Methanol extract showed a high percentage of DPPH scavenging activity of $85.11 \pm 1.0 \%$ followed by ethyl acetate $(68.01 \pm 0.5 \%)$, ethanol $(60.83 \pm 1.6 \%)$, n-hexane $(57.14 \pm 1.3 \%)$ and chloroform $(55.27 \pm 1.1 \%)$ extracts. Acetone and petroleum ether extracts showed least DPPH scavenging activity of $45.99 \pm$ $1.0 \%$ and $43.29 \pm 1.0 \%$ respectively. 


\section{Discussion}

The major components the essential oil of Artemisia spp. were of phenolics, flavonoids and tannins (19). The various degrees of microbial inhibitory effects of essential oil of $A$. absinthium, A. dracunculus, A. santonicum, and A. spicigera have been reported [10]. Though the essential oil of these species showed good antimicrobial activity they posses weak antioxidant activity $[17,18]$. In the present study, n-hexane extract of A. parviflora showed high level of antimicrobial activity for all the microbes tested with the MIC value of 32-64 $\mathrm{mg} \mathrm{mL}^{-1}$. Methanol, ethyl acetate and chloroform extracts of $A$. parviflora showed moderate antimicrobial activity compared to the ethanol, petroleum ether and acetone extracts. Growth of $P$. aeruginosa was inhibited by the n-hexane, ethyl acetate and methanol extracts compared to the antibiotics standards used.

The high microbial activity of n-hexane, ethyl acetate and methanol extracts could be attributed to the higher concentration of active antimicrobial agents like terpenoids, phenolics and volatile oils, in Artemisia species $[35,36]$. Good antimicrobial activity observed for n-hexane, methanol and ethyl acetate extracts of A. parviflora also could be due to the presence of terpenoids present. Terpenoids are one of the most abundant active antimicrobial agents isolated from plants $[37,38]$. The antibacterial activity of the terpenoids is mostly dependant on the interaction with the cell membrane of microorganisms. Terpenoids compounds interact with the lipid components of cell membranes, easily penetrate into the interior of the cell and kill the cells by interacting with the intracellular material [39-41].

In our study, n-hexane and methanol extracts showed good level of inhibition for $P$. aeruginosa, E. coli, $K$. pneumoniae, S. flexneri and B. subtilis. The phytochemical assay showed that the methanol extract of $A$. parviflora was abundant in phenolics. A. parviflora extracts can be also considered as a good source of phenolic substances like phenolic acids and tannins with a potential medicinal use. The active compounds present in these extracts may serve as good alternative for the conventional antibiotics drugs to treat multidrug resistance.

Phenolic compounds from plant extracts may contribute directly to antioxidant activity. Methanol extract of A. parviflora possesses high antioxidant activity. The total phenolics content of the A. parviflora was significantly high in methanol extract. The antioxidant activity of extract could be due to the presence of high content of phenolics, flavonoids and tannins. Although, A. parviflora extracts had low content of tannins and flavonoids, they showed good antioxidant activity. The n-hexane extract showed high antimicrobial activity but only showed moderate free radical scavenging activity with DPPH and FTC revealing that the active compounds found in the n-hexane showed less antioxidant activity when compared to methanol extract of $A$. parviflora. The active components of $A$. parviflora might be helpful in preventing or slowing the progress of various oxidative stress related disorders.

\section{Conclusions}

This study presents the antimicrobial activity against reference bacterial strains that are implicated as opportunistic as well as nosocomial infections, antioxidant activity and phytochemical components of the solvent extracts of $A$. parviflora. Further investigation is necessary to separate the active components and evaluate the antioxidant and antimicrobial activity of each component, so as to confirm the bioactive nature of these compounds.

\section{Competing interests}

The authors declared no potential conflicts of interests with respect to the authorship and/or publication of this article.

\section{Authors' contributions}

ARA performed the analyses, interpreted the results and prepared the manuscript. WH supervised the work, evaluated the results and corrected the manuscript for publication. Authors read and approved the final manuscript.

\section{Acknowledgement}

We thank SRM University for financial support.

Received: 30 March 2012 Accepted: 29 September 2012

Published: 21 November 2012

\section{References}

1. Tomlinson KL, Sanchez JA, Spasser MA, Schnase JL: Managing cognitive overload in the Flora of North America project. HICSS 1998, 2:296-296.

2. Mueller MS, Karhagomba IB, Hirt HM, Wemakor E: The potential of Artemisia annua L. as a locally produced remedy for malaria in the tropics: agricultural, chemical and clinical aspects. J Ethnopharmacol 2000, 73:487-493.

3. Eastman RT, Fidock DA: Artemisinin-based combination therapies: a vital tool in efforts to eliminate malaria. Nat Rev Microbiol 2009, 7:864-874.

4. Titanji VPK, Zofou D, Ngemenya MN: The antimalarial potential of medicinal plants used for the treatment of malaria in Cameroonian folk medicine. Afr J Tradit Complement Altern Med 2008, 5:302-321.

5. Rahman AF, Saleh MA: Nematicidal activity of phytochemicals from some arid land plants. Society of nematologists 45th annual meeting, Lihue, Hawaii. J Nematol 2006, 38:258-303.

6. Saddi M, Sanna A, Cottiglia F, Chisu L, Casu L, Bonsignore L, De Logu A: Antiherpevirus activity of Artemisia arborescens essential oil and inhibition of lateral diffusion in Vero cells. Ann Clin Microbiol Antimicrob 2007, 6:10

7. Meneses R, Ocazionez RE, Martínez JR, Stashenko EE: Inhibitory effect of essential oils obtained from plants grown in Colombia on yellow fever virus replication in vitro. Ann Clin Microbiol Antimicrob 2009, 8:8.

8. Matthew KM: The flora of the Tamilnadu. Carnatic series, Volume 1. Rapinat Herbarium, St. Joseph's College 1983, 3:1-2154.

9. Rana VS, Juyal JP, Blazquez MA, Bodakhe SH: Essential oil composition of Artemisia parviflora aerial parts. Flavour Frag J 2003, 18:342-334.

10. Kordali S, Kotan R, Mavi A, Cakir A, Ala A, Yildirim A: Determination of the chemical composition and antioxidant activity of the essential oil of Artemisia dracunculus and of the antifungal and antibacterial activities of Turkish Artemisia absinthium, A. dracunculus, Artemisia santonicum, and Artemisia spicigera essential oils. J Agric Food Chem 2005, 53:9452-9458.

11. Lai F, Sinico C, De Logu A, Zaru M, Müller RH, Fadda AM: SLN as a topical delivery system for Artemisia arborescens essential oil: In vitro antiviral activity and skin permeation study. Int J Nanomedicine 2007, 2:419-425. 
12. Xie G, Schepetkin IA, Siemsen DW, Kirpotina LN, Wiley JA, Quinn MT: Fractionation and characterization of biologically-active polysaccharides from Artemisia tripartite. Phytochemistry 2008, 69:1359-1371.

13. Caner A, Doskaya M, Degirmenci A, Can H, Baykan S, Uner A, Başdemir G, Zeybek U, Guruz Y: Comparison of the effects of Artemisia vulgaris and Artemisia absinthium growing in western Anatolia against trichinellosis (Trichinella spiralis) in rats. Exp. Parasitol 2008, 119:173-9.

14. Ribnicky DM, Kuhn P, Poulev A, Logendra S, Zuberi A, Cefalu WT, Raskin I: Improved absorption and bioactivity of active compounds from an antidiabetic extract of Artemisia dracunculus L. Int J Pharm 2009, 370:87-92.

15. Fiamegos YC, Kastritis PL, Exarchou V, Han H, Bonvin AMJJ, Vervoort J, Lewis K, Hamblin MR, Tegos GP: Antimicrobial and efflux pump inhibitory activity of caffeoylquinic acids from Artemisia absinthium against grampositive pathogenic bacteria. PLoS One 2011, 6:e18127.

16. Carlson HJ, Bissell HD, Mueller MG: Antimalarial and antibacterial substances separated from higher plants. J Bacteriol 1946, 52:155-168.

17. Zheng WF, Tan RX, Yang L, Liu ZL: Two flavones from Artemisia giraldii and their antimicrobial activity. Planta Med 1996, 62:160-162.

18. Ramezani M, Bazzaz FBS, Khadem SF, Dabaghian A: Antimicrobial activity of four Artemisia species of Iran. Fitoterapia 2004, 75:201-203.

19. Cha JD, Jung EK, Kil BS, Lee KY: Chemical composition and antibacterial activity of essential oil from Artemisia feddei. J Microbiol Biotechnol 2007, 17:2061-5.

20. Mangathayaru K, Sravan K, Reddy PK, Munikumar R, Swetha B, Reddy U: In vitro antioxidant studies of the aerial parts of Orianum majoram L. and Artemisia siversiana. Phcog Mag 2007, 3:90-94

21. Shi F, Jia X, Zhao C, Chen Y: Antioxidant activities of various extracts from Artemisia selengensis Turcz (LuHao). Molecules 2010, 16:4934-46.

22. Ahameethunisa AR, Hopper W: Antibacterial activity of Artemisia nilagirica leaf extracts against clinical and phytopathogenic bacteria. $B M C$ Complement Altern Med 2010, 10:6.

23. National Committee for Clinical Laboratory Standards (NCCLS): Methods for dilution antimicrobial susceptibility tests for bacteria that grow aerobically. Sixth Editionth edition. Wayne, PA, USA: Approved Standard - NCCLS document M7-A6; 2003.

24. Clinical and Laboratory Standards Institute (CLSI): Method for dilution antimicrobial susceptibility tests for bacterial that grow aerobically; approved standard - Eighth Edition. Wayne, PA, USA: CLSI document M07-A8; 2009.

25. Harborne JB: Phytochemical methods: a guide to modern techniques of plant analysis. London, Chapman and Hall, Ltd 1973, 2:49-188.

26. Trease GE, Evans WC: Orders and families of plant in pharmacognosy. Oxford University Press 1983, 12:343-383.

27. Pushker AK, Kaushik S, Lakhanpaul S, Sharma KK, Ramani R: Preliminary Phytochemical Investigation on the Bark of Some of the Important Host Plants of Kerria lacca-The Indian Lac Insect. Botany Research International 2011, 4(3):48-51.

28. Sofowora A: Research on medicinal plants and traditional medicine in Africa. J Altern Complement Med 1996, 2:365-372.

29. Krishnaiah D, Devi T, Bono A, Sarbatly R: Studies on phytochemical constituents of six Malaysian medicinal plants. J Med Plants Res 2009, 3:67-72.

30. Song FL, Gan RY, Zhang Y, Xiao Q, Kuang L, Li HB: Total phenolic contents and antioxidant capacities of selected Chinese medicinal plants. Int J Mol Sci 2010, 11:2362-2372.

31. Sim KS, Sri Nurestri AM, Norhanom AW: Phenolic content and antioxidant activity of Pereskia grandifolia Haw. (Cactaceae) extracts. Pharmacogn Mag 2010, 6:248-254.

32. Kim JS, Hyun TK, Kim MJ: Anti-oxidative activities of sorghum, foxtail millet and proso millet extracts. Afr J Biotechnol 2010, 9:2683-2690.

33. Yen GC, Wu J: Antioxidant and radical scavenging properties of extracts from Ganoderma tsugae. Food Chem 1999, 65:375-379.

34. Aiyegoro OA, Okoh Al: Preliminary phytochemical screening and In vitro antioxidant activities of the aqueous extract of Helichrysum longifolium DC. BMC Complement Altern Med 2010, 10:21.

35. Poiata A, Tuchilus C, Ivanescu B, lonescu A, Lazar MI: Antibacterial activity of some Artemisia species extract. Rev Med Chir Soc Med Nat lasi 2009, 113:911-4.

36. Suresh J, Reddy SVA, Ahuja J, Sebastian M, Rajan SK: Antioxidant and antimicrobial activity of Artemisia pallens. IJPI'S Journal of Pharmacognosy and Herbal Formulations 2011, 1:2
37. Solís C, Becerra J, Flores C, Robledo J, Silva M: Antibacterial and antifungal terpenes from Pilgerodendron uviferum (D. Don) florin. J Chil Chem Soc 2004, 49:157-161.

38. Gallucci MN, Oliva M, Casero C, Dambolena J, Luna A, Zygadlo J, Demo M: Antimicrobial combined action of terpenes against the food-borne microorganisms Escherichia coli, Staphylococcus aureus and Bacillus cereus. Flavour Frag J 2009, 24:348-354.

39. Gershenzon J, Dudareva N: The function of terpene natural products in the natural world. Nat Chem Biol 2007, 3:408-414.

40. Togashi N, Inoue Y, Hamashima H, Takano A: Effects of two terpene alcohols on the antibacterial activity and the mode of action of farnesol against Staphylococcus aureus. Molecules 2008, 13:3069-3076

41. Trombetta D, Castelli F, Sarpietro MG, Venuti V, Cristani M, Daniele C, Saija A, Mazzanti G, Bisignano G: Mechanisms of antibacterial action of three monoterpenes. Antimicrob Agents Chemother 2005, 49:2474-2478.

doi:10.1186/1476-0711-11-30

Cite this article as: Ahameethunisa and Hopper: In vitro antimicrobial activity on clinical microbial strains and antioxidant properties of Artemisia parviflora. Annals of Clinical Microbiology and Antimicrobials 2012 11:30.

\section{Submit your next manuscript to BioMed Central and take full advantage of:}

- Convenient online submission

- Thorough peer review

- No space constraints or color figure charges

- Immediate publication on acceptance

- Inclusion in PubMed, CAS, Scopus and Google Scholar

- Research which is freely available for redistribution 